\title{
The Influence of Hinduism toward the Islamic Practice of Indigenous People in Sulawesi
}

\section{Lilik Rita Lindayani ${ }^{1}$, I Nyoman Suarka ${ }^{2}$, I Wayan $\mathrm{Cika}^{3}$, Ni Luh Nyoman Kebayantini $^{4}$}

\author{
${ }^{1}$ Department of Languange and Literature, Halu Oleo University, Kendari, Indonesia \\ Email: lilik.rita@yahoo.com \\ ${ }^{2}$ Department of Jawa Kuno Literature, Udayana University, Denpasar, Bali, Indonesia \\ Email: nyoman_suarka@unud.ac.id \\ ${ }^{3}$ Department of Indonesian Literature, Uday ana University, Denpasar, Bali, Indonesia \\ Email: wayan_cika@unud.ac.id \\ ${ }^{4}$ Department of Sociology, Udayana University, Denpasar, Bali, Indonesia \\ Email: kebayantini@gmail.com
}

\begin{abstract}
Indonesia is divided in 3 (three) regions geographically, Western Indonesia covering Sumatra, Java, and West Kalimantan; Center Indonesia covering a part of Kalimantan, Sulawesi, and Bali; and Eastern Indonesia covering Maluku and Papua. Hinduism was developed firstly in Indonesia about 4-5th century, which is proved by the existence of oldest Hinduism kingdom, Kutai Kertanegara, East Kalimatan. This phenomenon creates a question about the ways or process of Hinduism culture goes into Indonesia and how the potention of Hinduism in influencing the islamic practice of Muslim people in Sulawesi is.This paper analyzes the influence of Hinduism culture towards islamic practice of indigenous people in Sulawesi, by using Totemisme Durkheim's theory (1964). The theory states that to understand the role in society, the researcher have to investigate the religion in its simplest and original form that cover all essential aspects, either in sacred or profane one. Logic definition method with qualitative and simbolic approaches in historic and normative ways are used to describe the role and spreading pattern of Hinduism culture that form the Islamic existence in Sulawesi. The data of this study qualitatively describe the influence of Hinduism towards Islamic practice of every ethnic in Sulawesi, either in custom speech, daily activity, or religious ritual.
\end{abstract}

Keywords-Influence of Hinduism, Islamic Practice, Indigenous People, Sulawesi

\section{INTRODUCTION}

Indonesia island which is located between Asia and Australia continents like bridge connecting two continents. Geographically, Indonesia is divided in 3 (three) regions, namely Western Indonesia covering Sumatra, Java, and West Kalimantan; Center Indonesia covering a part of Kalimantan, Sulawesi, and Bali; and Eastern Indonesia covering Maluku and Papua. Based on the geographic aspect, Indonesia is very strategic and it brings the Indonesian culture to be more dynamic. According Darini (2013:3) that there is not any culture that dose not change absolutely, it means that culture is always changing. Culture in Indonesian language comes from Sansekerta language, 'bhuddhayah', the plural form of buddhi and dhaya meaning everything that relates to mind or though (budhi) and ability to create (dhaya). In the fact, mind and creative power that is always moving have several steps. That is culture or civilization as the evidence of existence and development of a region or nation, which has relative values based on the owner society convention. Etymology science does not give much contribution in understanding the culture; semantic and comparison studies are very useful to discuss it.

The life of Arabic Muslim and Serani have much terms, and all are equivalent to culture as the value manifestation. By hadarat, it is emphasized to management and completing aspects. There is also a term, muruwah meaning ethnics humanism. Besides, it differs the term of umran badawi (primitive culture) and umran hadari (high culture). While, the term of tammadun or madaniyyah has closed meaning to civilization that often used to show opinion or assessment of culture development (Ranjabar, 2013:3). From those semantics examples can be seen that there is difference the culture approach in same object (Bakker, 1984:34-35). Further, culture is also viewed as civilization, even in Germany the culture is very identic to culture as well as in France and England. The civilization has complex meaning which relates to everything that should be kept and considered. It includes ethic, polite speech and acts, customs, good mind, glorious, etc. 
In Indonesia, the civilization has big role in influencing society order forming system, mainly Hindu and Is lam civilizations. Those go into Indonesia in simple relationship visiting, merchandising. Hinduism was developed firstly in Indonesia about 4-5th century, which is proved by the existence of oldest Hinduism kingdom, Kutai Kertanegara, East Kalimatan that is signed by yupa epigraph.

Based on several sources, Kutai kingdom with Hinduism characteristisc has developed in East Kalimatan that is signed by an epigraph. The epigraph has seven stone poles, which is called as yupa. One of the yupa mentions Mulawarman king who lead Kutai kingdom at that time. Mulawarman is written in the yupa because his donor in the amount of 20.000 cows to Brahmana. The physic evidence of oldest Hindu kingdom in Indonesia is not a questionable. However, in its development, Hinduism lives and develops rapidly in Bali about 10-11 century, while Islam went into Kalimantan about 15-16th Century. The picture of one of yupa stone poles with palawa writing can be seen below.

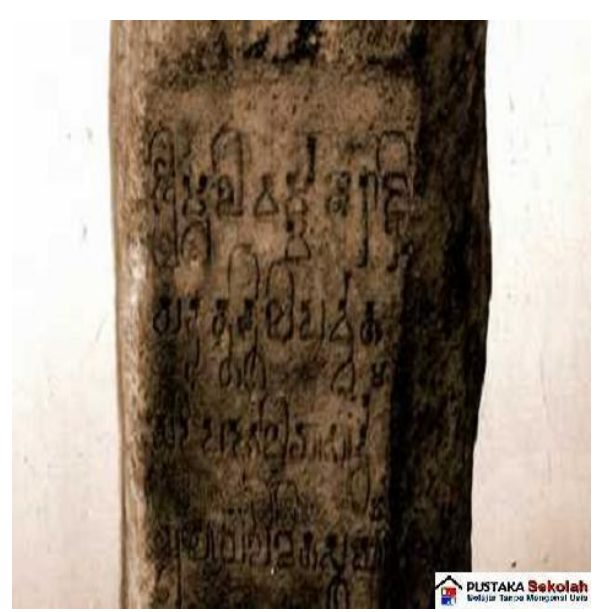

Fig. 1: Yupa Epigraph in East Kalimantan

Source: Pustaka Sekolah: http://kutai.blogspot.com

In Sulawesi, Hindu did not come physically as religion for its people, but Islam which is believed as the main religion and it is signed by applying Islam as the kingdom religion through persuasive approach. Islam went into Sulawesi for the first time about 13rd century. Todays, Islam is the main religion for most people in Sulawesi.

This paper does not investigate how the religions are receipt or believed, or how they live and develop, but the acculturation of cultures from Islam and Hindu as the interesting object to be discussed. It focuses on mainly from the geographic position of three islands in Indonesia center parts, namely Kalimantan, Bali, and Sulawesi.

In trilateral position, Kalimantan and Bali give historically much information, even in epigraph study and arceology excavation also has give explanation about the influence of Hindu and India culture, but they are not found in Sulawesi, mainly for the physic evidence of Hinduism. However, Budha belief that has inheritances through Budha archa in Sempaga City, South Sulawesi in the style of Amarawati from South India.

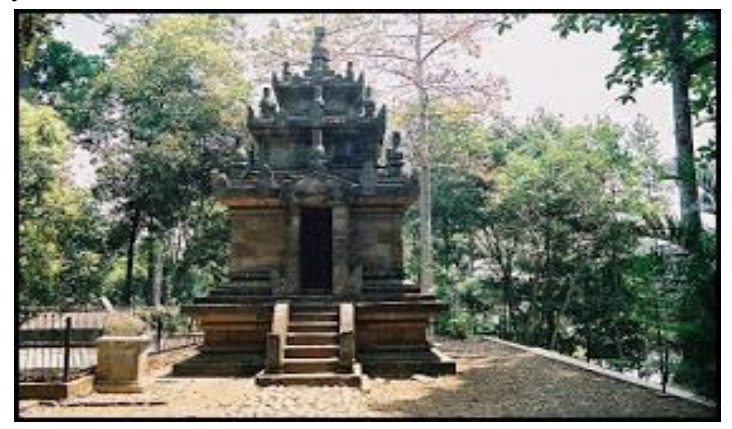

Fig. 2: Cangkuang Temple in South Sulawesi

Source :http://umiamanah.blogs pot.com

Budha went into Southeast Asia about 5-7th century. However, there is not any exact evidence because all writing or noting process are still based on identification and spreading of archas or sculptures. It is stated by Kang's statement about the history of Budha in Southeast Asia as in the citation below.

"Moreover, the history of Buddhism in Southeast Asia is not well known. Therefore, it is necessary to establish a chronology of Buddhist art in Funan to comprehend the ancient culture of Southeast Asia. If the few records in statue sare the only literary sources that remain, it is necessary to establish an arthistorical standard based on art styles. Regarding Indian Buddhist art, the history of art styles has been recorded comparatively well. Thus, the chronological records hould be based on a comparison with Indian Buddhist art. Considering the lack of records and texts, it is necessary to compare this record with Indian statues rather than to depend on vague presumptions. The earliest Buddhists culptures produced in Southeast Asia date from around the seventh century, and studies on earlier religious culptures are lacking. Excavated Hindu statues out number Buddhist statues, implying that Hinduism develop earlier than Buddhism in the area (Kang, 2013:42)."

Related to the existence of Cangkuang temple that Amarawati style from South India lines to conventions or findings of Budha archas in other regions of Southeast Asia. Coedes (1968,16-20), a prominent clergy and expert in Kang (2013:42) support it with detail information by stating that:

"The wooden Buddhist statues found in ÓcEo in the swamps of South Vietnam are good examples of early works. Several wooden Buddhists culptures were excavated in the ÓcEo wetlands, a region of ancient Cambodia-in other words, the territory of Funan. 
Some were damaged, but some remained intact. In particular, a wooden Buddhist statue found in Go Thapin P'ong Tuk should be considered the first example of religious art in Southeast Asia. The standing statue with both ankles visiblebe low the garment was assumed to have been created in the fifth century.

Coedes, aprominent scholar who laid the foundations for the study of Southeast Asia, believed the wooden statue wass culpted in the Amaravati style (Coedes 1968, 16-20). This style is characterized by a bare right shoulder and an arrow pleated garment with the hem falling above the ankles. However, given the condition of the statue, one can see only the body proportions with no stylistic details. Coedes must have determined the statue was model ledafter the Amaravati style by considering the influence from southern India, not by actually comparing the styles."

Related to the condition above, in folklore concept there are three aspects that should be ellaborated when giving finalization of identity between last and present time about the existence of people group and their beliefs, namely inheritances of oral culture, not oral culture, and half oral culture. This phenomenon is very interested to be investigated. Folklore or tradition and religion are very exosentric, united, but does not has center element. In other word, a religion will be more powerful when it brings other religion culture and tradition, and vice versa (Lindayani, 2015:710-712). Further, Flemming (2008) states the sprituality in indigenous people group that has more complex phenomena than its spritual aspect, as statement below:

"Indigenousv spirituality is a more complex phenomenon than the term spirituality alone, as generally understood, implies. Spirituality is closely bound up with culture and ways of living in Indigenous communities and requires a more holistic or comprehensive research approach. Two conceptual frameworks could help to orient Indigenous resilience research. One is then culturation framework."

Most of Sulawesi people are Muslim, and there is not any literature of spreading the Hinduism in Sulawesi. Before Islam, Sulawesi people have beliefs of animism and dinamism (custom religion). Nevertheles, in custom ceremony, speech system, and rituals in Sulawesi tend to Hinduism culture empirically.

This paper discusses the spreading pattern of Hinduism culture and the potention of Hinduism culture in influencing islamic practice of indigenous people in Sulawesi. It explains the function and role of Hinduism tradition as media for existence of Islam tradition and custom in Sulawesi. In qualitative way, the influence of
Hinduism towards Islam can be described in terms of speech forms, customs, and rituals.

\section{HINDUISM GOES INTO INDONESIA}

\section{Center Parts Process}

In culture social system, indonesian civilization is very important since it has closed relationship to culture. Totemisme Durkheim (1964) states that to understand the role in society, the researcher have to investigate the religion in its simplest and original form that cover all essential aspects, either in sacred or profane one. Nevertheles, in the researcher's view, the existence of sacred and profane that is followed by myth, worship, and ascetic practices for Muslim in Sulawesi is a part of intervention to keep values of society because Islam basically those practices have not any sources or bid'ah (Arabic: بـدعة). For this discussion, the anthropologists do not investigate not only the belief source but also belief issue and where the beliefs from are. The problems of religions genesis can be investigated through the history of its development.

In culture studies, there are several methods that can be used to investigate it, one of them is logic definition method with qualitative and symbolic approaches. This method is divided in two parts, (1) historically, a method that explain the inheritances for new generation from the culture object studied; (2) normative way, a method that is used to know the rule or life pattern of object studied and its values (Smith, 2001: 74). The relationship between this method and culture intervention observation can be seen from the history aspect of the culture that do intervention to other cultures, a religion to other religions. Cultural approach be able to give space to the new possibility to realize authenticity identity and value of people group (Hernowo:accessed Apr 16, 2017). So the formed patterns can be investigated its sources and intervention process. It lines to Mohd. Faizal (2017) that it relates to the pursuance of society interaction that is connected to the rules of Al-Quran as the holy book of Muslim. Al-Quran teaches the good relationship among human being. Although it brings firmness on certain aspects, but the fleccidity and good mind precede the firmness. Everything is done with good ethic, politely, good mind, wisdom ways, and good persuasive ways, even in debate condition.

In social system, tradition is collective needs, mainly the tradition as culture is not existed at moments' notice. It appears through the identification process for long time, so it is really belived in people heart. There is representation of the goals that will be reached. The purpose is to create unvisible power, but strong and become motivation for certain people group to keep and show the existence of the culture owners. Gazalba 
(1963:127) states that the culture change can be occurs if, (1) it is found new element; (2) new element that is borrowed or taken from other cultures; (3) the unsuitable culture elements to the environment, so it is moved and changed by something better; and (4) loss elements because of the inheritance failure.

The main point of the statement above is about the people knowledge, which is called folklore. Folklore or people knowledge is supposed as communication in small people group (Engelenhoven: 2015). Folklore is customs or story that is inherrited in hereditary, not booked, and collective culture. Folklore is plural fom and comes from base words, folk and lore. According Dundes (1980), the word 'folk' means certain people group with certain characteristics in terms of their physics, social, and culture, so they differ to others. Other characteristics are skin, hair, job, language, education condition, and religion. The most important in this case is they have certain tradition, namely culture that is inherrited in hereditary, at least two generations as together owners.

Hindu and Islam are two religions that go into Indonesia by using culture approach, so it inspirates much new cultures in Indonesia. In this case, one leaves integration prooves in diffusion pattern, and others are acculturation, as similation, and sincritism.

The history facts show that Hindu goes into earlier in Indonesia than Islam. The facts of Hinduism was developed firstly in Indonesia about the 4-5th century is not questionable, which is proved by the existence of oldest Hinduism kingdom, Kutai Kertanegara, East Kalimatan. In other hand, the history of Islam in Indonesia is still controversial, whether Islam is delivered by merchantmen from Gujarat which is called as Gujarat theory, or merchantmen from Arab which is called as Mekkah theory and Persia theory.

J.C. van Leur and O.W. Wolters state that the merchandising cooperation between Indian and Indonesia is earlier than between Indonesia and China (Poesponegoro, 1984:3). They do not mention the merchandising cooperation between Indonesia and Arab or Persia in the first time of the merchandising cooperation in Indonesia. So the dominant influence of India is more appeared in terms of the religion aspect, merchandising, or cultures. It is supported by the merchandising route about the 3rd century, in which Malaysia as the nearest neigbour country with Indonesia, that state historically about the merchandising route of India and China. Kra Isthmus as the region of Semenanjung Malaysia is used as sea transportation route, although it does not develop well. Further, Kang (2013: 17) states that sailor and merchantmen choose route of Kra Isthmus rather than through Semenanjung Malaysia because it is faster and nearer. When they arrive in Kra
Isthmus, they go through land route of Kra Isthmus and then use ship reboarded. It shows the strategic area of Kra Isthmus, and the government that lead this small area be able to dominate the sea merchandising.

The explanation above reinforces the analysis of the use of merchandising routes because it mentions the popularity of Malaysia land areas, in which Kalimantan and Malaysia are in one land geographically. In this case, Kutai Kartanegara in East Kalimantan is pionner of the existence of Hindu in Indonesia.

\section{HINDUISM POTENTION IN INFLUENCING THE MUSLIM PRACTICE OF INDIGENOUS PEOPLE IN SULAWESI}

Related the history notes, Indonesia geographically divided into Western Indonesia, Centern Indonesia, and Eastern Indonesia, as in the map below.

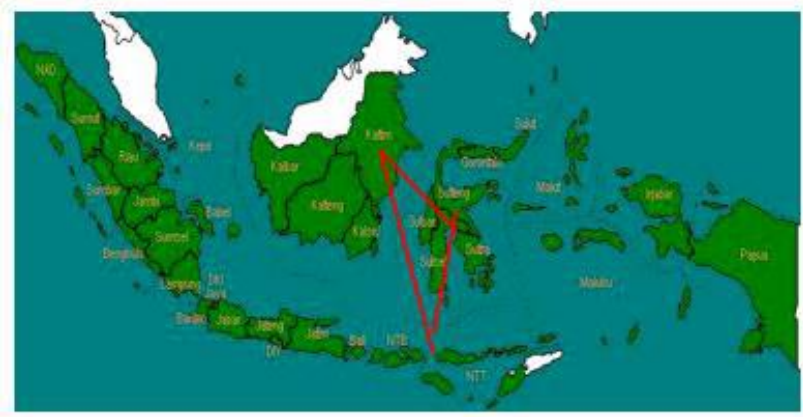

Fig. 3: Indonesian Map

Sources: $\underline{\text { https://his tory } 1978 \text {.wordpress .com/pemekaran- }}$ Indonesia-

Three red lines on the map are existed in Centern Indonesia Parts. In which, East Kalimantan is the first area for going of Hinduism into Indonesia. After East Kalimantan is Bali, and Hinduism lives and develops massively in Bali. and as dominant religion. In contrast, there is not any evidence of going of Hinduism in Sulawesi, mainly for the physic evidence, except Budha belief that has inheritances through Budha archa in South Sulawesi (it has been explained in the introduction). In Sulawesi, there are two big religions, namely Islam and Christian. Most Christian is in North Sulawesi and a part of Center Sulawesi, while Islam is dominant in South Sulawesi, Southeast Sulawesi, Gorontalo, and a part of Center Sulawesi.

The regions and its customs are the potention description of certain religion or belief to do intervention on society tradition order. However, tradition and religion are basically two different concepts.

Sulawesi is physically out of Hinduism supports. Nevertheles, society life order based on the observation that Islam in Sulawesi tends to do several Hinduism practices. However, the present of Hinduism is not massive like in Kalimantan, but rather than taught or 
delivered by certain personal. Hinduism culture in Kalimantan still lives and develops, mainly society tradition order of Dayak Kaharingan, which is called as animism Kaharingan Hinduism. It also looks on kingdom ethic order, mainly in Kutai Kertanegara Sultanate. Ritual of belimbur (self cleansing ritual ) in Erau ceremony, to memorialize the birth of Karang Melenu princess, the wife of first king of Kutai, Aji Batara Agung Dewa Sakti who is believed by the Kutai people as the God generation.

Likewise, Hinduism in Bali is acculturative, in which it is receipt and used in its culture, and the original culture still kept in society custom orders and its religious rituals. So, Hinduism in Bali is dfferent to Hinduism in India, but its essence as Siwa religion still maintained.

The influence of Hinduism culture in in the practice of indigenous people in Sulawesi can support the proof of Gujarat theory stating that Islam went into Indonesia through spreading which is done by merchantmen from Gujarat. So, it is possible to state that Islam in Sulawesi is Indian Is lam.

The involvement of Hindu in Sulawesi can be seen in soft concept, meaning it is not from religion spreading but through culture that is very effective and assimilative. In South Sulawesi, mainly in Sidrap regency, there is a community that is called ToLotang meaning 'south people' and they are Hinduism. Their first religion basic is a belief to the one God, which is called as Towani ToLotang (tradition religion). This community believe the one God who is called Dewata Seuwae and four elements of human being creations, namely ground, water, fire, and wind which is symbolized by sokko patanrupa (rice of four colors). The rice with four colors cover black rice that symbolizes ground, white rice that symbolizes water, red rice that symbolizes fire, and yellow rice that symbolizes wind. Those rices are always present on every ritual or ceremony. This community has affiliation to Hinduis $m$ through the order of government because every people in Indonesia have to choose one of five legal religions in Indonesia. This community then chooses to affiliation to Hinduism based on Decision Letter of Dirjen Bimas Hindu No. 2 in 1966 by consideration the similarity of their religious practices. Further, people in Southeast Sulawesi has several rituals in cleansing the heirloom goods and even in tradition ceremony like 'baca-baca' (praying in Muna ethnic) by using fire, myrrh, and ritual offerings that are basically forbidden in Islam as their religion. One of myrrhs with Hinduism esthetics of Southeast Sulawesi can be seen below.

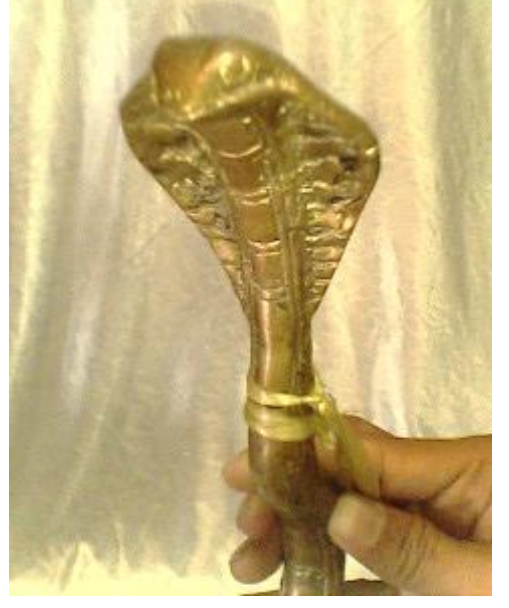

Fig. 4: Cobra Stick, one of the inheritances of Muna king generation

Source: Private colection

In addition, there is a naming to The Creator with Hinduism esthetic such as Sangia I Wawo Sangia 'Sky Arbiter God' (Tolaki ethnic) (Koodoh, 2011:22-23) in Hinduism term in Bali is "Sang Hyang Widi Wase"; and other is Barata (Bharata), naming for marine in Buton Sultanate (Darmawan ed., 2012; 64-65). It may be taken from the word of Bharatayudha which means 'sons battle'.

The order with Hinduism motives are still kept rapidly as the culture inheritance that is claimed as people tradition of Muslim (look at, Culture Change Theory (Gazalba, 1983:127). Simanjuntak (2016: 90) states that pursuance of people to do all tradition ceremonies caused of the development and keeping of phylosophy values as the culture essention in society thought. By this way, there is an effort to similarize the perception of religion and tradition through traditional practices and it then moves tradition concept to religion.

The belief order or religion pattern is completed if the people do tradition ceremonies. Belief dualism reflects that the people feel do justice acts with their religion. Tradition of reading magic formula in every traditional ceremony and traditional theraphy are still kept until now. Before reading magic formula, they say Bismillahirahmanirrahim (Arabic langauge) 'In the name of Allah, the most gracious, the most merciful'. In Islam, this sentence is always spoken before doing something, either before reading al-Quran or before doing all activities. One of the examples of magic formula is Kantisele theraphy on Muna ethnic in Southeast Sulawesi. It is soul restitusion magic formula. The word kantisele means 'soul restitusion', while its act called as kororo 'soul restitusion'. This magic formula consists of 5 (five) kinds (see Hasniati, 2014: 38). One of those five kinds of Kantisele is kantisele kahalano lalo (soul which is suprised when looking at something). This magic formula 
is used to treat patient or someone who has soul pressure after looking at something suprised. This magic formula speech is as follow.

\section{Bismillahirahmannirrahim}

'In the name of Allah the most gracious, the most merciful'

maemo wansororo 'come here please the soul'

koe wansohoro-horo tonuanamu 'do not loss your soul'

alako negholeo 'I take you in sun'

alako nekawea 'I take you in wind'

terserah inawamu 'depend on your soul'

alae we inawamu 'I take in your soul'

akoinawa matendiolo (can not be translated)

dadi panawarah 'please become as neutralizer'

Bismillah...' in the name of Allah'

korko...koko... (while blowing to pain loom for 3 times )

Other issue is about determining of good day and offday, which is called as Kutika Masuara. It has 5 (five) times, namely, Masuara, Kala, Sri, Brahma, dan Bisnu. In this kutika, one day is divided in 5 (five) parts, namely morning, forenoon, noon, towards the afternoon, and afternoon. Each day has different name, for example for morning time in the first day of month is called Masuara, the second day is called Bisnu, and so on by calculation of day 1 (one) - 5 (five).

Chart 1. Kutika Masuara

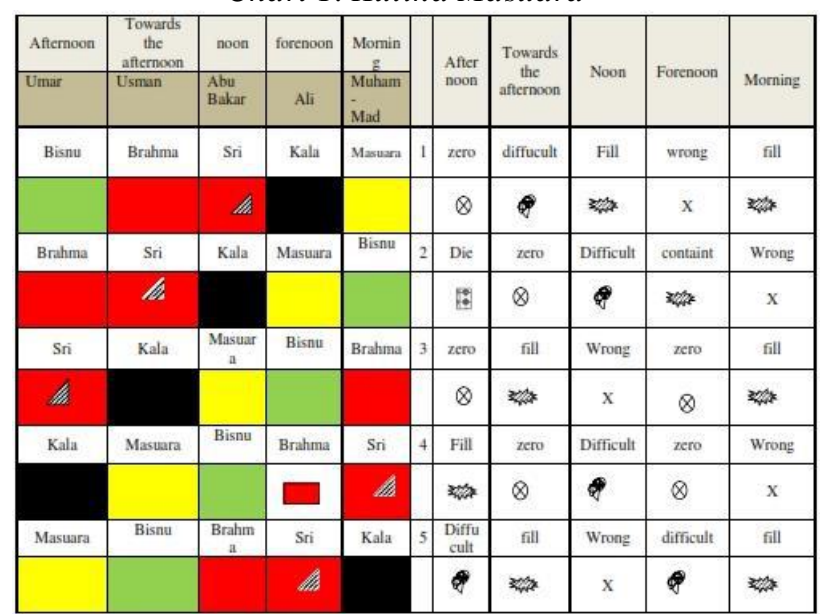

Sources: copy of Counvreur, 2001:232

(transcription from Bugis Language, South Sulawesi)

The chart above likes as asthrology calender that predict the natural signs through calculation the time empirically. For colors are as symbol for 4 (four) base elements, namely fire (red), water (yellow), wind (green), and ground (black). It is clear that there is acculturation between Hinduism and Islam on its patterns because in the first part, it is mentioned the name or Islam Prophet, Muhammad Salallahu Alaihi Wassalam and his Caliph, and it then mentions five Gods of Hinduism.

Some people in Sulawesi are very fanatic of calculation the time, mainly for keeping the profit and safety. They also believe the reincarnation, for example the death of children will give more ages for their parents or the birth of someone is the rebirth of his/her familiy who has died.

\section{CONCLUSION}

Based on the description above, it cocludes that the influence of Hinduism in Sulawesi is not only through the Hinduism line itself, but also through the continuous interaction in intensive and long time communication, so it can change the culture order in terms of the acculturation between Islam and Hindu in the form of meaningful folklore, which is often called as assimilative culture integration. According Das (in Hadiwijono, 1976:11) that Hindu is actually an anthropologic process which is then called as religion, having customs from one of or some nations. Therefore, Hindusim lives and develops with various beliefs and popular ritual. The context of Hinduism culture influence in Indonesian Center parts can be described in the pattern as follow.

\section{Chart 2.}

The Hinduism Influence of Indonesian Center Parts

Borneo

(by Diffusion Process)

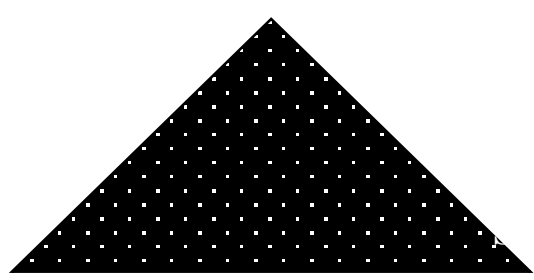

Bali

Sulawesi

(by Acculturation Process) (by Assimilation Process)

Other conclusion which is related to the Hinduism influence potention that the regions and its customs are the potention existence of a religion or belief that influence tradition and religious practice orders in the society who have different beliefs. It reinforces an assumption that tradition has certain power in society belief, so they always do it. The tradition value from other religions that is not considered by indigenous Muslim people in Sulawesi is viewed as ideal culture. It shows the intervention of certain religion becomes the reinforcement for other religion, and in this case is Islam. In other words, a religion will be more powerful when it brings other religion culture and tradition. It presents an influence that build variety collection, but is not in confession form. 


\section{REFERENCES}

[1] Bakker, J.W.M., 1984. Filsafat Kebudayaan (Sebuah Pengantar). Yogyakarta: Kanisius.

[2] Bell, Chaterine. 2009. Ritual Theory Ritual Practice. Oxford: Oxford University Press.

[3] Counvreur, J. 2001. Sejarah Kebudayaan Kerajaan Muna (terj. van Den Berg). Kupang: Artha Wacana Press.

[4] Dundes, Alan. 1980. Interpreting Folklore. Bloomington: Indiana University Press.

[5] Hasniati, 2014. "Bentuk dan Makna Mantra Kantisele pada Masyarakat Muna di Kelurahan Tiworo Kecamatan Tikep Kabupaten Muna Sulwesi Tenggara" (Thesis). Kendari: Universitas Halu Oleo.

[6] Hernowo,Bimo:https://www.researchgate.net/public ation/220036517 Beteng Vastenburg Butuh Interv ensi Kebudayaan [accessed Apr 16, 2017].

[7] Darini, Ririn. 2013. Sejarah Kebudayaan Indonesia Masa Hindu Budha. Yogyakarta: Ombak.

[8] Durkheim, E., 1964. The Rules of Sociological Method. Trans. S.A. Solovay \& J.H. Mueller. New York: The Free Press.

[9] Fleming, John and Robert J. Ledogar. 2008. Resilienceand Indigenous Spirituality:A LiteratureReview. Pimatisiwin: A Journal of Aboriginal and Indigenous Community Health 6 (2):47-64

[10] Gazalba, Sidi. 1983. Kebudayaan Sebagai Ilmu. Jakarta: Pustaka Antara.

[11] Hadiwijono, Harun. 1976. Agama Hindu dan Budha. Jakarta: BPK Gunung Mulia.

[12] Kang, Heejung. 2013. The Spread of Sarnath-Style Buddha Images in Southeast Asia and Shandong, China, by the Sea Route. KEMANUSIAAN the Asian Journal of Humanities 20 (1):39-60

[13] Koodoh, Erens E., Abdul Alim dan Bachruddin. 2011. Hukum Adat Orang Tolaki. Konawe: KP3D .

[14] Lindayani, Lilik Rita, et al. A Metaphorical Analysis of Kabhanti Modero to Show Munanese Social Relation. International Journal of Linguistics, Literature, and Cultur (IJLLC). Vol. 4 No. 2. Pages: 72-80,

March

2018. http//sloap.org/journals/index.php/ijllc/

[15] Lindayani, Lilik Rita. 2015. Tradisi Lisan Sebagai Media Evaluasi Eksistensi Bahasa Daerah. Jurnal Etnoreflika Vol. 4, No. 1. 710-712

[16] MohdFaizal,A. K.2017. Pendekatan normative dalam perbandingan agama: suatu analisis terhadap al-Quran. KEMANUSIAAN the Asian Journal of Humanities 24 (1):81-98
[17] Poesponegoro, Marwati Joenoed dan Nugroho Notosus anto. Sejarah Nasional Indonesia II. Jakarta: Balai Pustaka.

[18] Pustaka Sekolah: http://kutai.blogspot.com. download and visiting:12/07/2016

[19] Ranjabar, Jacobus. 2013. Sistem Soasial Budaya Indonesia (Suatu Pengantar). Bandung: Alfabeta.

[20] Simanjuntak, Bungaran Antonius. 2016. Tradisi, Agama, dan Akseptasi Moderenisasi pada Masyarakat Pedesaan Jawa. Jakarta: Yayasan Pustaka Obor Indonesia.

[21] Smith, Philip. (2001). Seri Cultural Theory, An introduction. U.K.: Blackwell Publishing Ltd.

[22] Amanah,Umi:http://umiamanah.blogspot.com.downl oad and visiting:10/06/2015

[23] Van Engelenhoven, Aone. 2015. SIFTL IX, Wakatobi 12-15 Juni 2015. Sultra. 